\title{
Curbing Free Speech: Strategic Lawsuits against Public Participation in India
}

\author{
Malcolm Katrak*
}

\section{Abstract}

There has been a sharp increase in the number of suits and legal notices threatening defamation. This substantial increase is due to the corporate companies aiming to stifle public discourse or bona fide criticisms. The apt term coined for defining these lawsuits is SLAPP (Strategic Lawsuits against Public Participation).Not only does this capture the causation, but also the consequences of these lawsuits. Curbing SLAPPs is essential, as it strikes at the root of democracy by not just affecting the defendant with frivolous claims, legal costs and hassles, but by also aiming at choking public discourse. This paper analyzes the issues relating to SLAPP suits and also the consequences of the same by examining various case laws. Thereafter, the author has suggested the need for Anti-SLAPP legislation and has also provided guidelines for formulation of the same.

Keywords: Author, Defamation, Free Speech, Public Discourse, SLAPPs

\section{Introduction}

When the humbled and esteemed writers request to the nouveau riche, an opportunity to put forward to the world their story, rarely is the proposal ever rejected. People have always been intrigued to peruse the lives of these corporate and political personalities,

* Law clerk to Justice (Retd.) S. N. Variava, Former Judge, Supreme Court of India; malcolmkatrak@yahoo.in 
normally referred to as corporate 'bigwigs',1 especially if they have broken their shackles and have risen through poverty. Unfortunately, but rather systematically, all of these bigwigs want themselves to be portrayed as the noble knights of the Templar, rising from the ashes. Business writings in India, as Subir Ghosh and Paranjoy Guha Thakurta put it:"Biographies of Indian businessmen hitherto had been unabashed hagiographies that would be eulogistic verbiage and obsequious idiom". ${ }^{2}$ The ironically the passive attitude of these personalities to control the writers can indeed be taken as a trampling of the integrity of the journalistic profession as a whole. For instance, Hamish McDonald an Australian, working for the reputed Far Eastern Economic Review (FEER) had taken upon himself to publish the truth about Reliance Industries and its Business Head Dhirubhai Ambani, after he was provided an opportunity by Dhirubhai himself, to publish a book about the journey of Reliance. Reliance Industries reacted equally strongly by sending a notice to the author even before the book saw the light of the day. The story of Hamish McDonald and his fight against the corporation has been taken as a case study further on in the paper. The honesty of the writers to show the actual picture, without adulteration, is the true spirit of journalism. Further, the importance of this freedom to the writers and press, lies in the fact that for most citizens the prospect of personal familiarity with newsworthy events is unrealistic. Thus, a fact, with sufficient evidence, revealed by the authors, is for the public authentic news to build an opinion on. It is the means by which people receive the information, often buried deep under, which is essential to intelligent self-governance. Fortunately, a few writers helped pave the way for the profession to usher in new meaningful business writings, including biographies, which is what is required in a democracy. ${ }^{3}$ The wrath of the bigwigs was another challenge that these writers faced, which came in various forms, inter alia, influencing the politicians to use their political power to slamming

1 Subir Ghosh \& Paranjoy Guha Thakurta, Sue the Messenger: How Legal Harassment by Corporates is Shackling Reportage and Undermining Democracy in India (2016)

2 Id.

3 Tamal Bandyopadhyay, Sahara: The Untold Story (2014) 
the writers with gag orders. Not many will be able to withstand this onslaught. ${ }^{4}$

The most infamous form came by way of Strategic Lawsuits against Public Participation, commonly referred to as SLAPP. Two professors of the University of Denver coined the acronym, which captures both the causation and the consequences:

We coined the name 'strategic lawsuits against public participation' in government, or SLAPPs to call attention to these cases in an emphatic way, and to illuminate both their cause and effect, and to encourage lawyers, judges, government leaders, and parties to look beyond labels and deal with them as a new, unitary type of litigation ${ }^{5}$

Decoding the term simply implies an increased tendency by those in power to silence public opinion and enfeeble protestors, thereby preventing them from dissenting any further. ${ }^{6}$

Strategic lawsuits are evolved by the rich and the powerful, who have the institutional capability to use the law to their advantage. Such persons are called 'repeat players'. They can maneuver the system to ensure that "the haves" have their say. ${ }^{7}$ The SLAPPs are becoming a substantial risk in any democracy, especially the ones which have a structure based on free speech and freedom of press. ${ }^{8}$ Reminiscent are the words of Rajiv Gandhi, "Freedom of Press is an article of faith with us, sanctified by our Constitution, validated by four decades of freedom and indispensable to our future as a Nation".9

4 Hamish McDonald, The Polyester Prince: The Rise of Dhirubhai Ambani (1998)

5 George W. Pring\& Penelope Canan, SLAPPs: Getting Sued for Speaking Out (1996)

6 George W. Pring, SLAPPs: Strategic Lawsuits Against Public Participation, 7 (1) Pace Environmental Law Review 3-21 (1989)

7 Marc Galanter, Why the "Haves" Come Out Ahead: Speculations on the Limits of Legal Change, 9 (1) Law and Society Review 95-160

8 Byron Sheldrick, Blocking Public Participation: The Use of Strategic Litigation to Silence Political Expression (2014)

9 B. R. Sharma, Freedom of Press Under the Indian Constitution (1993). 
Not every book, which is published, sees the light of the day, some are forced to abort at the nascent stage itself. Modern investigative journalists who write and investigate are perhaps in an even greater danger of seeing their work being sabotaged by unfortunate SLAPPs. Take for example, the case of Reliance Petrochemicals $v$. Proprietors of Indian Express, ${ }^{10}$ wherein the Supreme Court silenced the journalists of Indian Express from reporting instances of malpractice concerning the share issue of Reliance Industries. ${ }^{11}$ It is essential to understand how SLAPPs work in the domestic jurisdiction, specifically in India and its repercussions on democracy as a whole. This study guides the reader through the often-confusing and overlapping paths of civil and criminal defamation. The structural ambit of SLAPPs inter alia consists of a generic category affecting free speech under the guise of varied litigations.

\section{The growth of SLAPPs in India}

When a group of people go around shouting slogans, 'All Lawyers are Liars' or 'All Bureaucrats are Corrupt', a general statement as such cannot be termed as Defamation. However, when a direction has been laid against a particular community or company at large, the same can amount to defamation. ${ }^{12}$ This begs the ambit of who can be identified as the victim in such cases. In the former, no single person can be identified as the victim, however, in the latter, an individual can be identified as the defamed person. ${ }^{13}$ Sometimes, these facts turn out to be a major factor in churning SLAPP cases. Justice Nicholas Colabella described such compensation on defamation suits as, "Short of a gun to the head, a greater threat to First Amendment expression can scarcely be

${ }^{10}$ Reliance Petrochemicals v. Proprietors of Indian Express, (1988) 4 SCC 192 (India)

11See, Khushwant Singh And Anr v. Maneka Gandhi, AIR 2002 Delhi 58 (India)

12See Ellyn Tracy Marcus, Group Defamation and Individual Actions: A New Look at an Old Rule, 71 (5) California Law Review 1532 (1983).

${ }_{13} \mathrm{M} / \mathrm{s}$ Crop Care Federation of India v. Rajasthan Patrika Pvt. Ltd., Delhi High Court, CS(OS) 531/2005 
imagined"14.The use of these words first rung in the Delhi High Court in the case of $M / \mathrm{s}$ Crop Care Federation of India v. Rajasthan Patrika (Pvt.) Ltd.,15 wherein the plaintiff put an alleged defamation suit claiming damages to the extent of fifty lakhs, as the company was aggrieved by a series of newspaper articles published by the Rajasthan Patrika. The Court slammed the plaintiff saying that the defamation suit was nothing but stifling the aspect of free speech in a democracy, reiterating the words of Walter Lippmann, "Words are the bible of the democracy". ${ }^{16}$

Following Rajasthan Patrika was the Tata Sons Ltd. v. Greenpeace International $\mathcal{E} A n r$., in the Delhi High Court, ${ }^{17}$ a rather notorious case to prevent an NGO from providing bonafide criticism against the company's activities which endangered the Oliver Ridley Sea Turtles and their habitat.18 The plaintiff in this case sought damages worth ten crores over the alleged defamation. The Court dismissed the claim enumerating that all around the world, the courts have tried regulating grant of injunctions or gags against press, taking into account the essence of free speech, a fundamental aspect of any modern democracy. 19

The battle in SLAPP suits is nothing but free speech vis-à-vis the elite class. The case of National Stock Exchange of India v. Moneywise Media Pvt. $L t d .{ }^{20}$ is a testament to the rather unfortunate fact of the powerhouses' capabilities of filing SLAPPs. In this case, a whistleblower wrote a few letters along with attached evidentiary documents to substantiate the claims to Sucheta Dalal, a Mumbai based Journalist and the founder of personal finance magazine Moneylife. The claims were that the National Stock Exchange (NSE) was facilitating a few stockbrokers by massively

\footnotetext{
14 Gordon v. Marrone 21 ELR 21071

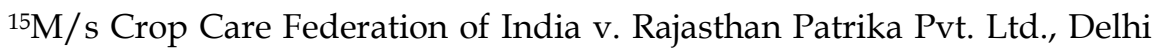
High Court, CS(OS) 531/2005

16 Walter Lippman, Liberty and the News (1920)

17Tata Sons Ltd. v. Greenpeace International \&Anr., Delhi High Court, (2011) DLT.705

${ }^{18}$ Id at Passim

${ }^{19}$ Id at Para 16

20 National Stock Exchange of India v. Moneywise Media Pvt. Ltd., Bombay High Court, NOM 1220/2015 in Suit No. 627/2015
} 
manipulating algorithm trading, a process of High Frequency Trading. Moneylife, thereafter tried to inquire and wrote corresponding letters and e-mails to NSE inquiring about the alleged manipulation. However, no correspondence from the side of NSE was provided by the officials. Later, the same letter by the whistleblower and attached documents were posted on the website of Moneylife. Agitated, the NSE thereafter filed a hundred crore defamation suit against Moneylife foundation. Gautam Patel, J., of the Bombay High Court, rather distinctively, used the Reynolds defense. ${ }^{21}$ The Reynolds defence was laid down in Reynolds $v$. Times Newspaper Ltd, whereby journalists were given qualified privilege in terms of publishing potentially defamatory comments in public interest. It further stated that where it is clear, that the journalist had a duty to publish an allegation even if it turned out to be wrong, the journalist cannot be held liable for the same. In adjudicating the Reynolds Defence, the court would be investigating the conduct of the journalist and the content of the publication. The court went further to fine NSE with fifty lakhs for the frivolous defamation suit. ${ }^{22}$

The aforementioned judgments have helped in paving a new way to absolve corporations with deep pockets from filing such suits and browbeat journalists and writers into submission. The institutions, which have faced crisis by defending such large claims in defamatory suits, have been rekindled by the thinking of the judiciary. The challenge, which now lies in front of the courts, is to find legitimate methods to restore public trust. Through the NSE case, the growth of SLAPPs in the country has fortunately been halted at the roots, for the time being.

\section{SLAPPs against writers}

Hamish McDonald, a writer, was intrigued with the life of Dhirubhai Ambani and the growth of Reliance Industries. The meteoric rise of Reliance in India and adjoining countries in Asia, provided a study for the economists, and a book about the man who ably built this empire was a motivational study for

21See Reynolds v Times Newspapers Ltd [2001] 2 AC 127.

${ }^{22}$ Supra at 20 
entrepreneurs. The Reliance story had McDonald in its grip, quoting

I was sucked in a bit. It was of course a good story. It was the usual story- that of an amazing tycoon who inspired the share ownership among the emerging Indian Middle Class, who managed to keep the share prices and dividends rising, who amazingly, through these years had held meetings in football stadiums and was kind of a rock star of the corporate world. 23

Seemingly, McDonald realized the true nature of the Reliance Industries after in-depth research and wanted to paint an honest picture. According to him, the corporation had politicians as puppets, thereby amending the rules and regulations to suit its business interests. ${ }^{24}$ McDonald thereafter fleetingly thought of writing a book to portray a true picture of the Reliance conglomerate, albeit having immense respect for the chairperson, Dhirubhai Ambani. Later, the The Polyster Prince: The Rise of Dhirubhai Ambani, was published in early 1998.25 Published by HarperCollins, the child of Hamish McDonald was able to see the light of the day, only to be provided an injunction by the Tis Hazari Court in Delhi. ${ }^{26}$ The publisher backed out by not providing any copies to the Indian Market and McDonald unfortunately was left to fend for himself against the biggest corporation in the country. ${ }^{27}$ The case study triggers questions inter alia the rights of the authors who are employed by the corporations to write biographies of their leaders, the authors' duty to put forward the true picture and the protection of authors' right to free speech. The words of McDonald provide a grim picture of the infringement of Fundamental Right of expression and free speech, "Let a book be published and then be sued. It's getting blocked even before it can hit the stands is a

\footnotetext{
23 Supra at 1.

24 Supra at 3.

${ }^{25} \mathrm{Id}$.

26 Supra at 1.

$27 \mathrm{Id}$.
} 
serious infringement on the right to free speech. I wish I find a publisher who is brave enough to publish the book in India." 28

The books and the stories that disappear, are sadly a casualty to the democracy. This isn't the first instance wherein the book has fallen to the mighty. In 2008, the Columbia University Press in New York published Peter Heehs' The Lives of Sri Aurobindo - a lifetime's work of Peter Heehs, which was banned by the Orissa High Court on the account of it damaging the beliefs of the devotees of Sri Aurobindo. ${ }^{29}$ The Gazette Notification stated that the book titled as "The Lives of Sri Aurobindo" by Peter Heehs contained objectionable matters depicting distorted facts about the life and character of Sri Aurobindo. Further, the state government is of the opinion that the said book contains matters which are deliberately and maliciously intended to insult religious beliefs of millions of Indians who idolize Sri Aurobindo as a National Hero and incarnation of "Almighty" and which promotes communal disaffection affecting public peace and tranquility, the publication of which is punishable under Sections 295A and 153A of the Indian Penal Code, 1860 (45 of 1860). It further elaborated on the grounds - (a) the book depicts wrong and distorted facts on the life and character of Sri Aurobindo, which is clearly blasphemous (b) the book contains absurd, irrelevant and self-made stories, which do not have any scriptural support and has caused widespread indignation amongst the devotees (c) the writings portrayed in the book have seriously hurt the sentiments of the apostles of Sri Aurobindo and the said book, with deliberate and malicious intention has insulted the religious beliefs of millions. A few other grounds were also mentioned for the steps taken by the Government. Therefore, in exercise of the powers conferred by Sub-section (1) of Section 95 of the Code of Criminal Procedure, 1973 (2 of 1974), its copies, reprints, translations or other documents containing extracts taken from there should be forfeited to the Government. Salman Rushdie's The Satanic Verses, banned by the Rajiv Gandhi

\footnotetext{
${ }^{28} I d$.
}

29 W.P. No. 15939 of 2008. Interestingly See S.R.O.NO.127/2009, Gazette Notification, $9^{\text {th }}$ April 2009:

See also, Sri Aurobindo Ashram Trust \&Ors. v. R. Ramanathan \&Ors Civil Appeal No. 12 of 2016. 
Government, is another example of how blasphemy is used as a shield in the secular state we call India. ${ }^{30}$

\section{SLAPPs and Deterrence}

A lawsuit is considered a SLAPP, primarily if the very fact of it being filed is likely to impose a chilling effect on the willingness of the defendant or others to participate in the public discourse. Chilling effect is the inhibition or discouragement of the legitimate exercise of natural and legal rights by the threat of legal sanction. The larger the damage it causes to the discourse, the higher the chilling effect it has. The Legal Harassment of authors/ writers/ publishers by these corporate sector giants provides for a nonfictitious scare absolving the initiation of the article into the public sphere. ${ }^{31}$ Further, it is the economic imbalance; throughout this paper, the author has provided case studies that show the powerhouses having deep pockets against publishers or newspaper houses having relatively meager amounts to defend these claims, lest paying such huge and rather idiosyncratic claims. Also, it is the aspect of unreasonable claim amounts, to choke the authors or the publishers. These claims are usually unsubstantiated. Often, the amount has no connection with the alleged damage caused by the publication. ${ }^{32}$ Further, SLAPPs being baseless lawsuits; generally, these lawsuits do not have foundation, no proof of loss of goodwill by the article nor can the company corroborate the allegations. ${ }^{33}$ Lastly, being the broad base jurisdiction of defamation suits.

The case study of the Indian Institute of Planning and Management (IIPM) and its director Arindam Chaudhari, provides for a grim reading of defamation laws. Chaudhari became the subject of a

\footnotetext{
30 Hassan Suroor, You Can't Read This Book, THE HINDU, March 3, 2012. See also, Alison Flood, Banning Salman Rushdie's Satanic Verses was wrong says Indian Minister, THE GUARDIAN, December 1, 2015.

${ }^{31}$ Kristen Ramussen, Fighting Frivolous Lawsuits Against Journalists: A State by State Guide to Anti-SLAPP Laws, Reporters Committee for the Freedom of the Press (April 15, 2017).

32 Supra at 9.

33Susan Lott, Corporate Retaliation Against Consumers: The Status of Strategic Lawsuits Against Public Participation (SLAPPs) in Canada (2004).
} 
Caravan cover story 'Sweet smell of success: How Arindam Chaudhari Made a Fortune Off the Aspirations- and Insecurities-of India's Middle Class'. Thereafter, Chaudhari reacted by filing a fifty crore defamation suit against Caravan magazine, not where the institute was based, nor where the defendant resided, which happened to be in Delhi, but in Assam. The court granted IIPM an injunction, ex parte, without hearing Caravan's side of the argument. Fortunately, the Supreme Court transferred the petition that was filed in Assam to Delhi, where the petition was in limbo until 2015.34 Thereafter, the bench of Justice Madan Lokur and Justice R K Agarwal described the same as a bogus litigation and dismissed it. All this while, IIPM had filed bogus SLAPP cases in different jurisdictions where there may have been one defendant residing or where a minute cause of action may have arisen. ${ }^{35}$ SLAPPs after all are frivolous lawsuits wherein the chance of their acceptance, apart from an ex parte order are extremely low, but the plaintiff continues to drag the defendant to fight a legal war in different jurisdictions, a point by the plaintiff to take revenge. Lastly, SLAPP affects the overview of the general public in a democracy, which allows free speech and expression. It sends a message that it is not limited to the specific issue or the defendant, but that the participation in public discourse is dangerous and it is likely to exact a heavy personal price. It deters investigative journalists from taking up issues of public importance or going against the government agencies or corporate sector giants.

\section{The Law of Defamation}

India retains both civil and criminal defamation and either can be used against the writers, once a legal notice has been issued. ${ }^{36}$ Civil defamation in India is not codified and an individual complaining of defamation may find recourse under tort law. If the work

\footnotetext{
34See, Daily Press v. Kishorendu Gupta \&Ors., Transfer Petition No. $837 / 2011$.

${ }^{35}$ Maheshwer Peri, How we defeated IIPM's Campaign to silence the truth with Defamation Laws, HUFFINGTON POST, Sept. 27, 2016; See also, Samir Nazreth, When Law is blind, THE HINDU, March.01, 2013.

${ }^{36}$ Arvind Kejriwal v. Arun Jaitley, Delhi High Court, Crl. M.C. 2417/ 2016 (India).
} 
adversely affects the reputation of the person, the contents of the work enable a third person reading the work to identify the person being defamed or prevent him from publishing defamatory material. Criminal defamation on the other hand requires intention (mensrea) to cause harm to reputation of the person defamed. ${ }^{37}$ Proving the presence of an intention to harm a person's reputation is a condition precedent to conclusively establish defamation. The meaning of harm for the purposes of defamation under the Indian Penal Code (hereinafter referred to as 'IPC') is restricted to harm to the reputation. ${ }^{38}$ Under Civil defamation, the publisher/author has a few defenses to an action for defamation which include truth, an absolute defense as well as fair comment, which protects the expression of an opinion by a person. A fair comment is such a comment which is true, or which, if false, expresses the real opinion of its author; such an opinion having been formed with a reasonable degree of care and on reasonable grounds. Lastly, the defense of Privilege, which contemplates and identifies certain occasions, circumstances or situations when a person's right to free speech outweighs another's right to reputation. ${ }^{39}$ Criminal defamation on the other hand, has ten exceptions enumerated under Section 499 of the IPC. 40 The section includes a true statement made in public good, a comment or opinion made in good faith against the conduct of a public servant discharging his public functions or his character, comment about the conduct or the character of the person when such conduct touches a public question, a substantially true report of any judicial proceedings, criticisms of merits of the case which has been decided made in good faith, expression of opinion on author's performance which the author submits to the judgment of the public, comments in nature of censure expressed in good faith, accusation about a person made in good faith, imputation about the character of any person made in good faith and cautioning another person in good faith against another person. 41 The law of defamation seeks to protect imputations against the property or reputation of the

\section{${ }^{37} \mathrm{Id}$.}

${ }^{38}$ Indian Penal Code, § 500, 1860.

${ }^{39}$ Anish Dayal, How defamation works in India, WALL ST.J., Apr. 19, 2017.

40 Indian Penal Code,1860, § 499.

$41 \mathrm{Id}$. 
person. However, the major issue is the reconciliation of defamation against the aspect of free speech and expression. Article 19(1)(a) guarantees to the citizens, the right to freedom of speech and expression albeit with certain restrictions under Article 19(2) wherein defamation plays a pivotal role. Free speech holds cardinal value, which is paramount to the constitutional scheme and is part of the basic structure of the Indian Constitution, a violation of which would violate the aspect of liberty enshrined under Article 21 of the Constitution of India. ${ }^{42}$

The Supreme Court in the case of Subramaniam Swamy v. Union of India ${ }^{43}$, whilst providing the rationale behind anti-defamation laws stated, "The right to freedom of speech and expression is not an absolute right...A person's right to freedom of speech has to be balanced with the other person's right to reputation." A SLAPP has three core implications against the general speaking community:

(a) the basis of a criminal defamation suit runs through the veins of Article 21 of the Constitution which has been interpreted to constitute the right to reputation, thus availing a constitutional protection to file SLAPPs4;

(b) SLAPPs are often considered as a show of might to stifle the media community as a whole; and

(c) It has an inhibitive effect on free speech and expression. For instance, in 1997, the activist, writer and journalist, Madhu Kishwar began the examination of Dr. Prabha Manchanda's clinic in respect of certain gynecological operations. After having an inkling that the said article would not be a hagiography, Dr Manchanda filed a defamation suit in respect of future publications to stifle the journalist before the article was even published. 45 These types of suits may be termed as "anticipatory defamation suits". Thus, the journalist is more often drawn into a litigation battle to protect his

\footnotetext{
${ }^{42}$ INDIA CONST. art. 19, cl.2. \& art.21, 1950

43 Subramaniam Swamy v. Union of India, Writ Petition (Crl.) No. 184 of 2014

44 Board of Trustees of Port of Bombay v. Dilipkumar Nadkarni, (1983) 1 SCC 124; State of Bihar v. Lal Krishna Advani, (2003) 8 SCC 361

45 Dr. Prabha Manchanda v. Samira Kohli and Madhu Kishwar, Civil Suit No. 233/1997
} 
free speech. On the other hand, the courts have put a valiant effort in protecting the free speech of the publishers and the press when the government has aimed to curb their voices. An example of that could be witnessed through the famous Auto Shanker's case where the government officials tried to restrain the publication on the grounds of protection of their right to reputation. The Supreme Court opined that public officials cannot hide behind the cloak of defamation suits. ${ }^{46}$ While doing this, the Apex Court relied on the English decision in Derbyshire County Council v. Times Newspaper47 and the famous American decision New York times v. Sullivan ${ }^{48}$. Companies having financial clouts have often used the SLAPP mechanism to undermine Article 19(1) (a) to protect the right of reputation. The main strategy utilized is to showcase the financial might to intimidate the press and authors into submission. Thus, it becomes necessary for the courts to understand whether a defamation suit should be considered as a SLAPP. The judiciary has turned a blind eye towards the plight of authors and above all, modern investigative journalist and their right to free speech. The message from the judiciary seems to be to let the nation get on with providing corporations a safety valve to maintain their reputation and slaughter those who stand in the way of these corporations.

\section{The road ahead}

The Law of Defamation was drafted to protect the victims who have been hampered by the irresponsible and rather negligent comments by the media houses. However, the course has changed and this has now been used to gag media outlets, individuals, authors, writers etc. The stakeholders have increased and with the same, there is a considerable rise in frivolous lawsuits. ${ }^{49}$ The burden, which falls on the judiciary, is not only to protect the innocent, but also to act as a watchdog against such suits, which try

\footnotetext{
${ }^{46}$ Rajagopal v. State of Tamil Nadu (1994) 6 SCC 632 (India)

47Derbyshire County Council v. Times Newspaper (1993) 1 All ER 1011 ${ }^{48} \mathrm{New}$ York Times v. Sullivan (1964) 376 US 254

${ }^{49}$ See, Balco Employees Union v. Union of India (2002) 2 SCC 333 (India); Center for Indian Trade Unions v. Union of India and Ors CWP No. 2456 of 1996 (India); SonakkaGopalgawda v. U.R.Anantha Murthy AIR 1988 Kant 255
} 
to destroy public discourse. The outcry has never been greater. The change of players as well as the power relations between the sides has resulted in the lawsuits filed against small groups and organizations. Although, the judiciary has played a major role in preventing the indefinite rise of such lawsuits, it still has a long way to go. ${ }^{50}$

\section{VI.1 Anti-SLAPPs Legislation: Special Motions and Beyond}

There is an immediate need to make Anti-SLAPP legislation. The governance of civil defamation has been through the Civil Procedure Code and the Criminal Cases take their own separate route, but a separate Anti- SLAPP legislation is a must. ${ }^{51}$ This legislation may govern the special motion, which any public person may be able to file against the plaintiff in such lawsuits. The special motion will have two advantages - the first being, the expedient hearing procedure as soon as the motion is filed. Second, being the Plaintiff showing a prima facie case of damage to reputation. If in the Special Motion, the plaintiff is able to show by preponderance of evidence the rising of cause of action and proving the legal action, then the court shall allow the Plaintiff and the Defendant to file their respective claims and replies. Inability of the Plaintiff to show the damage to reputation in the Special Motion will provide for a dismissal of the case along with the motion and costs. It is pertinent that the legislation has a procedure, which is in consonance with the time frame provided in the Code of Civil Procedure, but with a different set of guidelines formulated for the special motion. This will help provide for a speedy disposal of SLAPP cases. The legislation will have a twofold effect: (a) it will provide for strict standards to be followed in the Special Motion hitherto for all defamation cases which would help in deciding whether there is a cause of action which has arisen and assess the reasonableness or good faith of the publisher/author. (b) It

${ }^{50}$ See, RomeshThappar v. State of Madras 1950 SCR 514 (India); S. Rangarajan v. P. Jagjivanram (1989) 2 SCC574 (India); Bobby International v. Om Pal Singh (1996) 4 SCC 1(India)

51 Hugh Wilkins \& Pamela Shapiro, Breaking the Silence: The Urgent Need for Anti SLAPP Legislation in Ontario, Canadian Environmental Law Association (2010) 
provides for a balance to the right to access courts and right to freedom of speech, both being essential fundamental rights.

The second part of the legislation must deal with the aspect of de minimisnon curatlex (the law does not concern itself with trifles), albeit a general exception in the IPC. Defamation cannot be trivial in nature, if the writings are on issues which are trivial in nature, the same must be discarded by the court or after the special motion as mentioned above is filed. The legislation must have different standards laid down for different kinds of publications inter alia biographies and investigative research. The divisions help in understanding the degree of harm to the reputation, which has been caused to the Governmental agency or the Corporate Company, if any. It helps in understanding the aspect of good faith as also assists the court in facilitating the defendant if the author is not backed by a media outlet or a publisher to protect himself from such lawsuits. Lastly, the legislators must understand the concept of defamation and the rise of defamation cases in different geographical locations all around the country. Consider a case where the defendant's publishing house is situated in Delhi, where the Plaintiff resides in Delhi, where the cause of action arose in Delhi but for the minute harm caused in Karnataka, the Plaintiff files a lawsuit in Karnataka. The courts in Karnataka must refrain from allowing such lawsuits and must dismiss the same immediately. It is the legislator's responsibility to curb such loopholes and amend the laws.

There is no single mechanism which may curb the malice of SLAPP's but legislation is the first step towards the goal of achieving success without hampering the right to access justice and right to free speech. To not understand the defendants' predicament in filing of the defense or conceding to the corporation, is a literal slap on the concept of democracy. Hence, the author believes that no legislation whatsoever will curb such malice even with the suggestions provided above, without compulsory legal costs to the plaintiff, if the same turns out to be a SLAPP or a frivolous lawsuit. These legal costs must be not less than twenty percent of the total claim alleged by the Plaintiff. The case of NSE and IIPM provides for a good study to understand the 
paradigm of the stakeholders involved and the effect it has on the authors at the micro level and the public at the macro level.

\section{Conclusion}

In India, the SLAPP phenomenon has been on the rise, starting from the curious case of Rajasthan Patrika to SLAPP against Greenpeace. The only way a democracy, which allows for right to access justice and right to free speech can go forward is to provide for comprehensive laws. In Australian Capital Territory, the Protection of Public Participation Act, 2008 protects measures intended to disrupt the democratic process and to influence public opinion. In the United States, twenty-nine states have enacted Anti SLAPP laws. ${ }^{52}$ In India, however, there is little dedicated research on SLAPPs by the legislators, to the effect that it has on the stakeholders viz. the authors, and publishers. The sole purpose of journalists and writers is to maintain the status quo and if the power is subverted in the hands of the Government agencies or corporate companies, it is their duty to challenge that status quo, in the interest of transparency and democracy. 53 It is time that the legislators understood that the aspect of SLAPP cannot be dissociated from the talks of defamation and free speech. As it is rightly put, "There are some who shoot the messenger; then there are those who sue. The casualty in both cases is the democracy." 54

Marc Randazza, The need for a unified and cohesive national AntiSLAPP Law, 91 Oregon Law Review (2017).

53 Muhammad Nasir, Role of Media in a Developed Society, 5(2) Interdisciplinary Journal of Contemporary Research In Business (2013).

54 Supra at 1 